\title{
The analysis of congested infrastructure and capacity utilisation at Trafikverket
}

\author{
M. Grimm \\ Trafikverket, Swedish Transport Administration, \\ Sweden Planning Department, Capacity Analysis, Sweden
}

\begin{abstract}
The capacity utilisation in the Swedish rail network remains constantly high. The competition between approximately forty different railway operators applying for timetable slots continues. Trafikverket performs analysis of the railway capacity with different methods and tools. The calculation of the capacity utilisation is performed annually for the entire railway network. It is based on a common European standard described in the Capacity Leaflet UIC 406. This paper presents the implementation of this method in Sweden as well as the recent results. Trafikverket has, during the annual capacity allocation process, since the year 2007 declared different sections of the network congested. The capacity of congested sections is then analysed in order to find solutions for capacity shortages. Trafikverket performs timetable analysis with the tool TrainPlan and simulations with the tool Railsys. Trafikverket investigates the timetable robustness, calculates headways between trains operating on the double track and defines some guidelines for traffic planners.

The Southern Main Line that connects the first and third biggest cities in Sweden- Stockholm and Malmö- has been congested during 2011. This paper presents the variety of methods used while analysing this congested line. In particular, the cooperation with Linköping University within the field of punctuality and timetable robustness is mentioned here, with particular focus on the punctuality studies of the Southern Main Line.

Keywords: capacity utilisation, capacity allocation, congested infrastructure.
\end{abstract}




\section{Introduction}

The Swedish Transport Administration, Trafikverket, is a two year old authority responsible for planning of maintenance and development of the entire transport system in Sweden. The authority deals with all transport modes including the railway system. The Capacity Analysis Department deals with development and implementation of different methods and computer based tools to cope with short and long term railway system planning matters. The employees of the department have their origin at former Banverket, the Swedish Rail Administration.

Trafikverket is cooperating since many years with different research groups in Sweden. The cooperation with the Royal Institute of Technology (KTH) covers the field of operation analysis with analytical models and simulations (see Lindfeldt [1]). The cooperation with Uppsala University is focused on train traffic control systems and in particular the train dispatcher's man machine interaction (MMI) (see Wikström et al. [2]). The recent research made in cooperation with Linköping University deals with scheduling and operation analysis with optimisation. Within this cooperation there are some studies of the timetable robustness made concerning the Southern Main Line that became congested in 2011 .

\section{Capacity of the railway system}

There are many definitions of the railway capacity due to different time horizons in planning and due to dissimilar requirements from decision-makers. The problems are solved and decisions made in several steps of railway planning and operations. The definition and understanding of the capacity itself varies during the whole process (see figure 1) [3].

\section{Capacity utilisation calculation}

Trafikverket calculates the capacity utilisation in the entire network once a year (see Grimm and Wahlborg [4]).The calculation has been made and reported for the contribution to the Annual Report since 2001. The calculation is based on the international standard, the Capacity Leaflet UIC 406 [2] and focuses on the line capacity. The leaflet itself is actually under development in order to define and calculate capacity in nodes.

Today the Swedish railway network consists of approximately $13500 \mathrm{~km}$ of railway track, mainly single track (about $8000 \mathrm{~km}$ ). Traditionally the network is divided into separate lines that has been gradually built since the middle of XIX century (see figure 2).

The passenger train routs connect the cities and several regions. They deliver service to a nation of totally about 9.5 million citizens who are mostly settled down in the southern part of the country. The freight traffic is still heavy and, generally, the traffic in the entire main network is heterogeneous. 


\begin{tabular}{|c|c|c|c|}
\hline $\begin{array}{l}\text { Market } \\
\text { (customer } \\
\text { needs) }\end{array}$ & $\begin{array}{l}\text { Infrastructure } \\
\text { Planning }\end{array}$ & $\begin{array}{l}\text { Timetable } \\
\text { Planning }\end{array}$ & Operations \\
\hline $\begin{array}{l}\text { Expected } \\
\text { number of } \\
\text { train paths } \\
\text { (peak) }\end{array}$ & $\begin{array}{l}\text { Expected } \\
\text { number of train } \\
\text { paths (average) }\end{array}$ & $\begin{array}{l}\text { Requested } \\
\text { number of } \\
\text { train paths }\end{array}$ & $\begin{array}{l}\text { Actual } \\
\text { number of } \\
\text { trains }\end{array}$ \\
\hline $\begin{array}{l}\text { Expected mix } \\
\text { of traffic and } \\
\text { speed (peak) }\end{array}$ & $\begin{array}{l}\text { Expected mix of } \\
\text { traffic and speed } \\
\text { (average) }\end{array}$ & $\begin{array}{l}\text { Expected mix } \\
\text { of traffic and } \\
\text { speed }\end{array}$ & $\begin{array}{l}\text { Actual mix of } \\
\text { traffic and } \\
\text { speed }\end{array}$ \\
\hline $\begin{array}{l}\text { Infrastructure } \\
\text { quality need }\end{array}$ & $\begin{array}{l}\text { Expected } \\
\text { conditions of } \\
\text { infrastructure }\end{array}$ & $\begin{array}{l}\text { Existing } \\
\text { conditions of } \\
\text { infrastructure }\end{array}$ & $\begin{array}{l}\text { Actual } \\
\text { conditions of } \\
\text { infrastructure }\end{array}$ \\
\hline $\begin{array}{l}\text { Journey times } \\
\text { as short as } \\
\text { possible }\end{array}$ & $\begin{array}{l}\text { Time } \\
\text { supplements for } \\
\text { expected } \\
\text { disruptions }\end{array}$ & $\begin{array}{l}\text { Time } \\
\text { supplements } \\
\text { for expected } \\
\text { disruptions }\end{array}$ & $\begin{array}{l}\text { Delays caused } \\
\text { by operational } \\
\text { disruptions }\end{array}$ \\
\hline $\begin{array}{l}\text { Translation of } \\
\text { all short and } \\
\text { long-term } \\
\text { market } \\
\text { induced } \\
\text { demands to } \\
\text { reach } \\
\text { optimized load }\end{array}$ & $\begin{array}{l}\text { Maintenance } \\
\text { strategies }\end{array}$ & $\begin{array}{l}\text { Time } \\
\text { supplements } \\
\text { for } \\
\text { maintenance } \\
\text { Connecting } \\
\text { services in } \\
\text { stations } \\
\text { Requests out } \\
\text { of regular } \\
\text { interval } \\
\text { timetables } \\
\text { (system times, } \\
\text { train stops } \\
\text { etc.) }\end{array}$ & $\begin{array}{l}\text { Delays caused } \\
\text { by track } \\
\text { works } \\
\text { Delays caused } \\
\text { by missed } \\
\text { connections } \\
\text { Additional } \\
\text { capacity by } \\
\text { time } \\
\text { supplements } \\
\text { not needed }\end{array}$ \\
\hline
\end{tabular}

Figure 1: Different views of capacity.

For calculation purposes, the railway network is divided into 249 line sections. The calculation is performed for two time periods: a whole day ( 24 hours) and the two hours period with the most intense traffic (below called "max 2 hours"). 


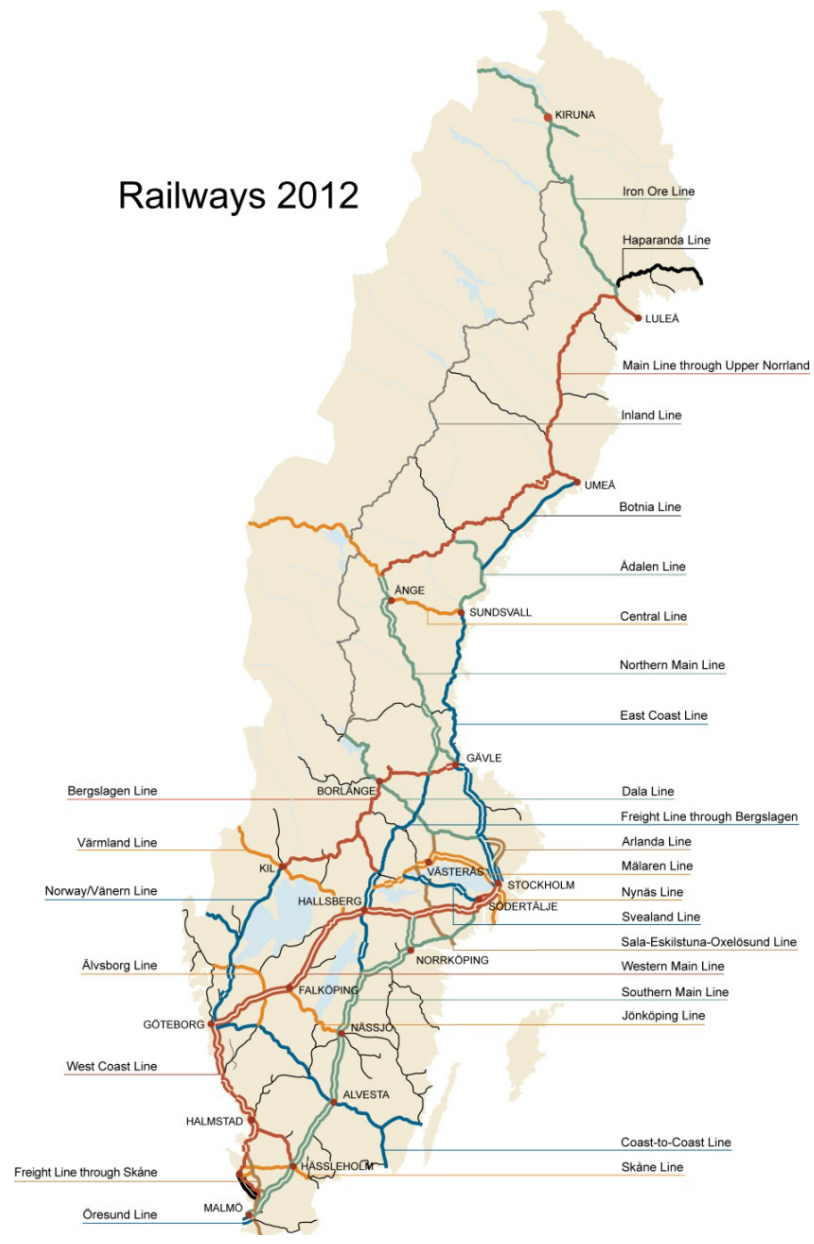

Figure 2: $\quad$ Railway lines in Sweden.

For each line section the result indicates the level of capacity utilisation that causes capacity balance, problem or shortage. There is no capacity spared in the shortage sections. The risk of punctuality disturbances to occur is high and the demand of more slots is hard to meet in those sections. At sections with high traffic density during the whole day there is a need of detailed planning of maintenance activities as they cause high inconvenience to the railway operators and their customers.

The results of calculation that was performed at late autumn 2011 are presented in figure 3. Nineteen line sections of totally 249 suffer from capacity shortage during the whole day. They are located around the biggest cities in Sweden: Stockholm, Göteborg and Malmö as well as along the Southern Main Line, the Western Main Line, the East Coast Line, the Freight LineT Bergslagen, the Iron Ore Line and the Northern Mail Line. 


\begin{tabular}{|l|l|l|}
\hline Capacity utilisation level & \multicolumn{2}{|l|}{$\begin{array}{l}\text { Number of line sections for two } \\
\text { calculation periods respectively }\end{array}$} \\
\cline { 2 - 3 } & The whole day $24 \mathrm{~h}$ & Max 2 hours \\
\hline Shortage $(81-100 \%)$ & 19 & 95 \\
\hline Problem $(61-80 \%)$ & 35 & 56 \\
\hline Balance $(<60 \%)$ & 192 & 95 \\
\hline Closed for maintenance & 3 & 3 \\
\hline Total number of lines & 249 & 249 \\
\hline
\end{tabular}

Figure 3: $\quad$ Railway capacity utilisation in Sweden 2011.

On the other hand, 192 line sections have balanced capacity utilisation.

As far as "max 2 hour" period is concerned, when the competition of most attractive slots is most intense, 95 line sections suffer from capacity shortage.

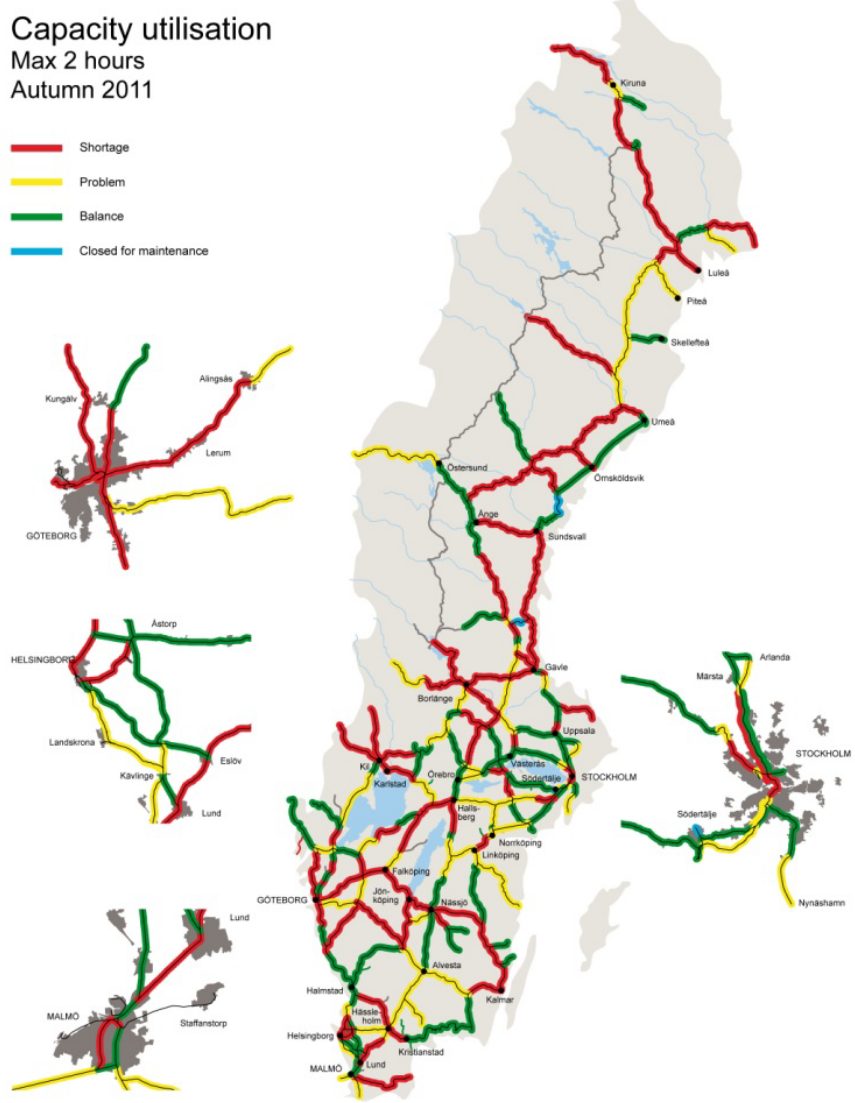

Figure 4: Capacity utilization in Swedish railway network in 2011, results for the two hours period with the most intense traffic. 
For better understanding of the results and the distribution of the different capacity utilisation levels in the network, we produce maps that are published annually on the internet (see figure 4).

The recent innovation in the calculation method is an explicit presentation of line sections that has been closed for maintenance purposes during at least six months in 2011. There were three such line sections in Sweden then.

The calculation is still performed half- manually. A time consuming steps are the search for information concerning changes in the infrastructure and a laborious analysis of the traffic statistics that indicate changes in traffic distribution. To identify the "max 2 hour" period for each line needs detailed studies of the timetable too.

\section{Methods for capacity analysis of congested railway lines}

The Swedish railway market has been gradually deregulated. In October 2010 the freight traffic was deregulated and in December 2011 the passenger traffic. There are several operators competing for attractive slots during the annual capacity allocation process. Some capacity shortage problems cannot be immediately solved. Then, the sections with capacity lack are declared congested.

Trafikverket has, since the year 2007, stated different sections of the network congested. The number and location of these line sections differ from year to year (see figure 5). There were seven congested line sections in the railway network in 2011. This year we investigate three capacity conflicts.

\begin{tabular}{|l|l|l|l|l|l|}
\hline Timetable & T08 & T09 & T10 & T11 & T12 \\
\hline Decision taken in the year & 2007 & 2008 & 2009 & 2010 & 2011 \\
\hline $\begin{array}{l}\text { The number of congested } \\
\text { lines }\end{array}$ & 3 & 0 & 1 & 7 & 3 \\
\hline
\end{tabular}

Figure 5: $\quad$ The number of congested line section each year during 2007-2011.

For example the Southern Main Line that connects the biggest and the third biggest cities in Sweden- Stockholm and Malmö- has been congested during timetable 2011. Different kinds of capacity studies, involving different methods and tools, were performed to find the solution to the conflict.

The Southern Main Line is an electrified railway line. It is approximately 600 $\mathrm{km}$ long and consists mostly of double track. The highest line speed in several sections is $200 \mathrm{~km} / \mathrm{h}$. There is a wide variety of trains operating at different speeds along the line: local and regional commuter trains, freight trains and long distance trains.

The traffic in a day in 2011 with average density along the Southern Main Line consisted of 13 trains of type X2000 in each direction between Copenhagen/Malmö - Stockholm running at a speed of $200 \mathrm{~km} / \mathrm{h}$ and two long- 
distance trains in each direction with the maximum speed $160 \mathrm{~km} / \mathrm{h}$. Interregional trains operated on parts of the line: north of Katrineholm, between Katrineholm and Linköpin as well as between Malmö and Alvesta. Besides, three commuter train systems were operating along the line: Malmö - Höör (Skånetrafiken), Tranås - Norrköping (Östgötatrafiken) and Gnesta - Stockholm (Storstockholms lokaltrafik). The commuter train services usually have cyclic timetables and operate at a maximum speed of $140-180 \mathrm{~km} / \mathrm{h}$. The number of freight trains was in average 28 in each direction.

The congested section was located between Mjölby and Norrköping (see the infrastructure scheme in figure 6 and traffic density in figure 7).

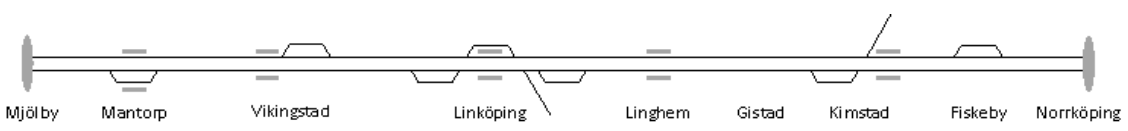

Figure 6: The infrastructure scheme of the congested section.

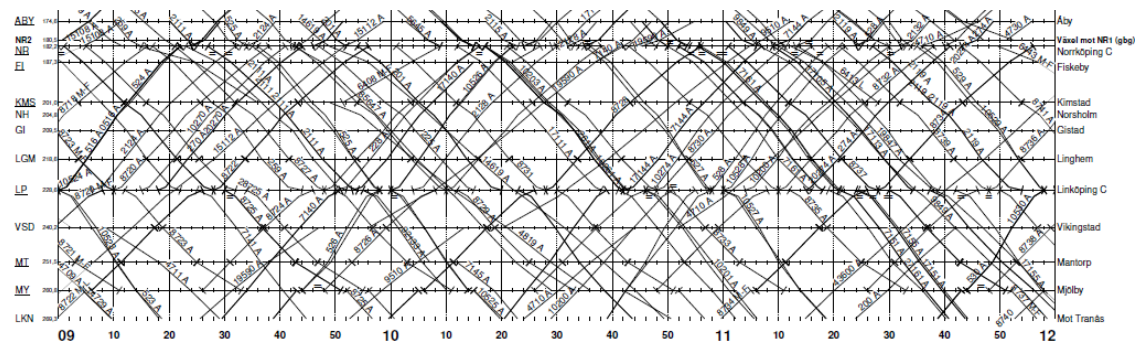

Figure 7: The traffic density at morning rush hours along the congested section.

The decision in 2011 to declare the line section congested was based on the demand from a local traffic operator that wished a regularity of its timetable. The conflict between locally operated trains and long distance fast trains had to be solved.

For this purpose, there were different studies of the congested Southern Main Line performed during the period $16^{\text {th }}$ September $2010-15^{\text {th }}$ September 2011:

- timetable analysis

- headway calculations

\subsection{Timetable analysis}

The line capacity utilisation for the Southern Main Line has been calculated. Furthermore, different structures of timetables have been examined in the TrainPlan planning tool. Because of the high capacity utilisation caused by high degree of variations of train speeds and additional train stops at the stations, it was not possible to deliver a cyclic timetable for all local trains' slots. 


\subsection{Headway calculations and scheduling guidelines}

The capacity shortage in 2011 along Southern Main Line resulted in development of analysis methods and wider usage of Railsys tool at Trafikverket.

In order to develop and in advance communicate some scheduling guidelines, Trafikverket has started to perform more systematically headway calculations for different traffic situations along double track sections with high capacity utilization.

The investigations of the signalling system's impact on the railway line capacity is the basic step in most analysis (see also Grimm and Sandblad [5]). Such calculations are performed in Railsys simulation tool and calibrated in cooperation with scheduling and operational staff. Once validated, the simulation tool is a convenient analysis instrument and can be used for investigations of a huge amount and type of parameter dependencies (see also Grimm [6]).

In particular, the analysis of the congested in 2011 Southern Main Line delivers theoretical headway calculation results. Two following fast trains (X2000) and two following freight trains have been studied to avoid signalling interaction. Furthermore, some overtaking situations for different train combinations have been investigated too. These calculations are translated into detailed scheduling guidelines that may be followed during the capacity allocation process in the future.

\subsection{Timetable robustness}

To promote better understanding of the timetable robustness and its impact on punctuality, Trafikverket cooperates with Linköping University within a project "Robustness of Railway Timetable" (RTJ). The analysis of the timetable deals with the influence of distribution and size of time margins on the robustness and punctuality of train services. The operation analysis is made by optimization.

The researchers put focus on the Southern Main Line. They have monitored traffic along this line and investigated in particular the punctuality of two longdistance trains X2000 running from Malmö to Stockholm (see Andersson et al. [7]). These trains run at a speed of $200 \mathrm{~km} / \mathrm{h}$ and the shortest journey lasts 4 hours and 15 minutes. Ongoing studies investigate the punctuality of other train types running along the Southern Main Line.

\section{Conclusions}

Analytical models together with simulation and optimization tools are convenient for railway capacity analysis. Trafikverket cooperates with different researchers to contribute to development and implementation of these models and methods. The recent field of development is timetable robustness and operation analysis by optimization. 
Trafikverket performs annually capacity utilization calculations for the entire network. The authority performs continuously capacity analysis studies, in particular to cope with capacity shortage along congested railway lines.

\section{References}

[1] Lindfeldt, O., Railway Operation analysis - evaluation of quality, infrastructure and timetable on single and double-track lines with analytical models and simulation, Doctoral Thesis in Infrastructure, KTH, Stockholm, 2010.

[2] Wikström J., Kauppi A., Hellström P., Andersson A. W. and Sandblad B., Train traffic control by re-planning in real-time, Computers in Railways $I X$, WIT press, 2004.

[3] UIC Capacity Leaflet 406, $1^{\text {st }}$ Edition, June 2004.

[4] Grimm, M., Wahlborg M., Kapacitetssituationen 2009 - Banverkets järnvägsnät, Banverkets rapport 2009-03-31, ISSN/ISBN.

[5] Grimm, M. Sandblad, B., Simulation of different signalling systems, Computers in Railways VII, WIT Press, 2000.

[6] Grimm, M., "Simulation as a Method to Analysing the Capacity of a Railway System", The $1^{t t}$ International Seminar on Railway Operations Modelling and Analysis, IAROER, Delft, The Netherlands, 2005.

[7] Andersson E., Peterson A., Kraseman J.T., Robustness in Swedish Railway Traffic Timetables, The 4th International Seminar on Railway Operations Modelling and Analysis, IAROR RailRome, Italy 2011. 